\title{
Determinants of Career Choice of Agricultural Profession among the Students of College of Agriculture in Maharashtra state, India
}

\author{
Adedapo, A. O.*, Sawant, P. A., Kobba, F. and Bhise, R. N. \\ Department of Extension Education, Dr. Balasaheb Sawant Konkan Krishi Vidyapeeth., Dapoli. Pin-415 712, \\ District - Ratnagiri, Maharashtra State, India.
}

\begin{abstract}
The purpose of this study is to identify factors that influence the career choice of Agricultural profession among the Students of College of Agriculture, Dr. Balasaheb Sawant Konkan Krishi Vidyapeeth, Dapoli, Maharashtra State, India. A total of 120 respondents were randomly selected for this study and structured questionnaire was used to elicit information from the students. Descriptive statistics, Likert scale and regression analysis were used to analyze the data collected. The respondent's age ranged from 19 to 44 years with an average age of 22.6 years. They belonged to all the religion practice in the country. More than half of the respondents were male, they are from farming families and had rural background in their childhood. Seven variables significantly influenced the choice of career of agricultural profession which includes; Personal interest (mean $=2.50)$, guidance or mentor (mean 2.15), parents (mean $=2.13)$, media or contacts with agricultural experts (mean $=2.03$ ), previous educational performance (mean $=2.01)$, location of childhood $($ mean $=1.96)$ and work experience before admitted into college of agriculture (mean $=1.92)$. Most of the respondents perceived agriculture as a stepping stone to other professions, poor man's job, required enormous capital, rural people's job and laborious. The challenges that hinder the continuity in the agricultural profession are financial constraint, land acquisition, unpredicted future, climate change, marketability, labour, seasonality and/or perishability of agricultural commodities. The regression analysis result validates the significant relationship between influence of parents, mentor, educational performance, work experience, childhood background, family income and parent occupation on the choice of agriculture as a course and profession among youths in the University. The study recommends early stimulation of student's interest in agriculture, provision of grants to graduates who wish to start agricultural enterprises and modification of school practical experiences towards commercial agriculture.
\end{abstract}

Keywords: Agricultural profession, choice, experience, farm work

\section{Introduction}

Agriculture in India plays an essential role that meet the basic necessity for food, clothing, nutritional security, shelter and economic growth. Its remains the mainstay of Indian economy as well as the main source of livelihood for more than $70 \%$ of the populace, contributing about $17 \%$ to the national Gross Domestic Product (GDP), $26 \%$ to national income, employment for over $60 \%$ of the populace, foreign exchange and more importantly, approximately half of India's populace and neighbouring countries depends on agriculture and allied sectors for their livelihood (Annual report 2010-11, Ministry of Agriculture, Govt. of India). "Agriculture connects economic growth and rural poor" but "its importance goes beyond incomes and poverty reduction by lowering and stabilizing food prices; improving employment for poor rural dwellers; increasing demand for consumer goods and services, and to encourage growth in non agricultural economy" (OECD, 2006).

The annual growth rate in GDP has increased from less than $6 \%$ during the initial years of reforms to above $8 \%$ in recent years. This happened because of rapid growth in non-agricultural sector. The workforce employed in agriculture between 1980 - 1981 and 2006 - 2007 witnessed diminution; from $60.5 \%$ to $52 \%$. One of the challenged with Indian economy is the diminution in the share of agricultural labours in the whole workforce has been gradual than the diminution in the share of agriculture in the GDP. For instance, the share of agriculture and allied activities in the GDP reduce from $57.7 \%$ in 1950 - 1951 to $15.7 \%$ in 2008 - 2009 while the total workers reduced from $75.9 \%$ in 1961 to $56.4 \%$ in 2004 - 2005 (Sundaram, 2001, 2007). Due to this the difference between labour productivity in agriculture and non- agriculture shoot-up rapidly.

These resulted into two consequences. First is the migration of rural dwellers in which educated youths move to urban areas where many capital investment projects and lucrative job opportunities are available. The degree of this rural-urban migration has effect on man power supply and agricultural productivity. Second, farmer population is ageing such that capital productivity, man power supply and output have reduced. The effect of ageing could amount to about 30\% reduction in rural labour in the next ten years (Bloom and Reenen, 2010). Thus, despite the impart of agriculture to the growth of economy, there are inadequate labour force and required skill resulting from the lack of interest by the youth in choosing agriculture as their professional career. The youths see agriculture as an exclusive activity of poor rural sector that lack basic social amenities such as 
electricity, educational and health care institutes, good roads network, financial institutions etc (World Bank, 2012) makes it unattractive to live in.

Schooling is one of the cultural and socio-economic factors that affect the choice of career of the youths (Ferry, 2006). Farming is considered as a default occupation among the rural dwellers with little or no education and even rural youths with little or no access to higher education may decide to take possession of family farm to continue farming activities (Wilson, 2008). Availability of resources such as land and credit facilities also influences choice of agriculture as a career. The influence of age group/friends is also an important factor in making decision on professional career (McVicar, 1996; Esters and Bowen, 2004; Azubuike, 2011). Early intervention in a child's career plays essential role in the choice of a career. One of the essential factors that influence girl's career choice is opportunity which is associated with social class and economic status of her parent. The important occurrence in child's life often appears to influence her career choice. For instance a prolonged illness which resulted that the child spends much time in hospital can interest the child to become a nurse or doctor when he/she grows up. Educational career is strongly influenced by family background and home experiences (McVicar, 1996, Hammond et al., 2007, Faulkner, 2009). Parents who are literate do want their children to take up their careers but this is not so in the agricultural profession. The farmers wish their children to become professionals in other fields rather than agriculture, due to strenuous way of life and hardship experienced. Thus, student's enrolment into college/university of Agriculture is one of the least compare to technological or other professional Universities in India.

Thus, despite the prospects of agriculture, it is rated poor among the populace. Since the prominent turning point in youth's lives involves the career choice they make, therefore the need to ask some pertinent questions arise: Should we allow this to continue? What are the factors that influence choice of agricultural career? What are the professions that youth are interested in? Are they ready to stay on the profession? What can we do to encourage them to stay in agricultural profession? What are the challenges faced by the youth to achieve their goals in agricultural profession? What are the possible solutions to sustain agricultural profession? These are the questions that this study aims to find answers to in the choice of Agricultural profession as a career among the agricultural student in DBSKKV, Dapoli, India.

\section{Methodology}

The study was carried out in College of Agriculture, Dr. Balasaheb Sawant Konkan Krishi Vidyapeeth, Dapoli, Maharashtra State, India in year 2014. The University is located at Dapoli which is the tahsil place at north side of Ratnagiri district and is the main campus of the University. Dapoli is a small town situated at 250 $\mathrm{M}$ above sea level with annual rainfall $3500 \mathrm{~mm}$, the minimum and maximum temperature ranges between $11^{\circ} \mathrm{C}$ to $33^{0} \mathrm{C}$ due to proximity to sea and the climate is humid. However, it results to pleasant climate throughout the year. The total population is 9697 of which $5027(51.84 \%)$ were male while $4670(48.16 \%)$ were female (Census, 2011). The major crops grown in Dapoli are rice and nagli in Kharif season while the fruit crops are mango, cashew, coconut and arecanut. It is also connected to Mumbai, Pune and Kolhapur by road and 30Km to railway station in Khed. Dapoli is having Nagar Panchayat, which is at present under the control of an administrator, almost all the government department have sub-divisional/ taluka level offices. It is also one of the best education centers in the region having facilities of secondary and higher education medium in Art, Sciences, commerce and agriculture.

A random sampling technique was used in selecting 120 respondents from students of the College of Agriculture utilized for this study. A structured questionnaire was used to obtained information from the respondents on their socio-economic characteristics, factors influencing their career choice of agriculture profession and the choice of staying on the job after the course of study. Descriptive statistics, Likert scale and regression analyses were utilized to analyze the data collected. 


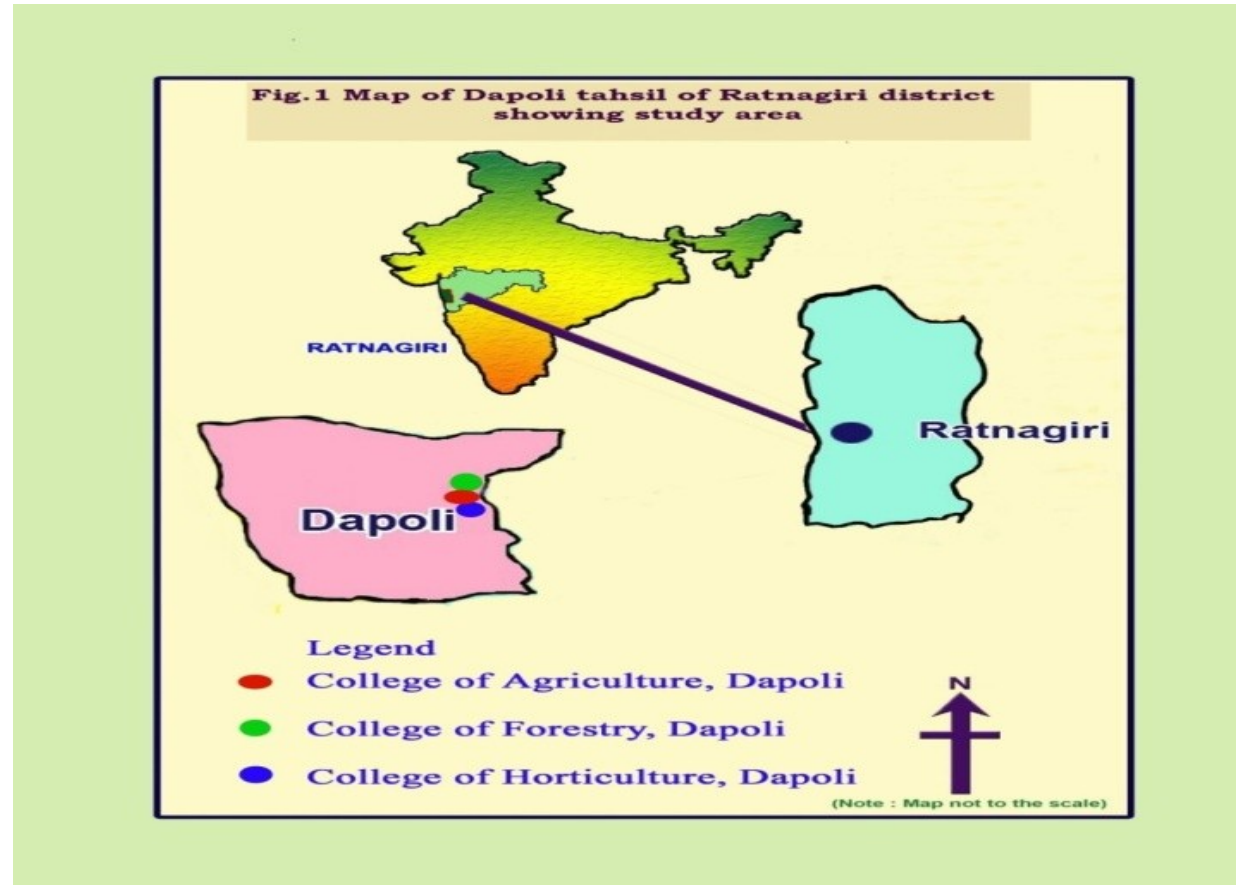

Fig. 1 Map of Dapoli showing study area.

\subsection{Socio-economic Characteristics of Respondents}

\section{Results and Discussion}

Table 1 reveals respondents age ranged from 19 to 44 years with a mean age of 22.6 years whereas more than half of the respondents were below the mean age and this have strong influence on their choice of career; they cut across all religious practices within the country but majority $(85 \%)$ being Hindu. There were more male respondents $(63.33 \%), 58.33 \%$ grew up in rural areas, $46.67 \%$ were from farm families, more than half of the respondent live below the mean (Rs. 255697.42/-) family annual income and $43.33 \%$ had farming experience before entering into the University. With these features, they are likely to create interest in agricultural professions.

Table 2. Socio-economic Characteristics of the Respondents

\begin{tabular}{|c|c|c|c|}
\hline Variable & Frequency & Percentage & Mean \\
\hline \multicolumn{4}{|l|}{ Age (Years) } \\
\hline $19-22$ & 62 & 51.67 & \\
\hline $23-26$ & 52 & 43.33 & 22.6 \\
\hline $27-30$ & 04 & 3.33 & \\
\hline Above 30 & 02 & 1.67 & \\
\hline \multicolumn{4}{|l|}{ Gender } \\
\hline Male & 76 & 63.33 & \\
\hline Female & 44 & 36.67 & \\
\hline \multicolumn{4}{|l|}{ Religion } \\
\hline Christianity & 8 & 6.67 & \\
\hline Muslim & 6 & 5.00 & \\
\hline Hindu & 102 & 85 & \\
\hline Buddhism & 4 & 3.33 & \\
\hline \multicolumn{4}{|l|}{ Educational Level } \\
\hline P. hD & 14 & 11.67 & \\
\hline Masters & 66 & 55 & \\
\hline Undergraduate & 40 & 33.33 & \\
\hline \multicolumn{4}{|l|}{ Father's Occupation } \\
\hline Farmer & 56 & 46.67 & \\
\hline Government worker (Service) & 53 & 44.17 & \\
\hline Business & 4 & 3.33 & \\
\hline No father & 7 & 5.83 & \\
\hline \multicolumn{4}{|l|}{ Mother's Occupation } \\
\hline Farmer & 11 & 9.17 & \\
\hline Government worker (Service) & 12 & 10 & \\
\hline Business & 2 & 1.67 & \\
\hline Housewife & 91 & 75.83 & \\
\hline No mother & 4 & 3.33 & \\
\hline Family Annual Income (Rs.) & & & \\
\hline
\end{tabular}


Below 100,000

$100,000-300,000$

$300,001-500,000$

Above 500,000

Location of Childhood Home

Rural Areas

Urban Areas

Present course of study

General Agriculture

Agricultural Economics

Extension Education

Biotechnology

Horticulture

Animal Husbandry

Entomology

Plant Pathology

Plants Breeding and Genetics

Agronomy

Farming experience before

entering into the University

Yes

No

$\begin{array}{cc}48 & 40 \\ 31 & 25.83 \\ 31 & 25.83 \\ 10 & 8.34 \\ & \\ 70 & 58.33 \\ 50 & 41.67 \\ & \\ 34 & 28.33 \\ 12 & 10 \\ 20 & 16.67 \\ 4 & 3.33 \\ 14 & 11.67 \\ 10 & 8.33 \\ 8 & 6.67 \\ 4 & 3.33 \\ 6 & 5.00 \\ 8 & 6.67 \\ & \\ 52 & \\ 68 & 43.33 \\ & 56.67\end{array}$

Source: Field Survey, 2004.

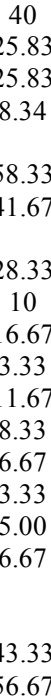

255697.42

\subsection{Perception of agricultural profession}

Figure 1 reveals that $70 \%$ of the respondents perceived agriculture as a stepping stone to other profession, only $6.67 \%$ of the respondents perceived it as a poor man's job, 53.33\% perceived it as being laborious, $65 \%$ perceived that it requires enormous capital, $54.17 \%$ perceived that there is no ready-made market for it, $45 \%$ perceived it to be illiterate's job while $65.83 \%$ of the respondents perceived it to be rural dweller's occupation. Thus most students have negative perception towards agricultural profession and there is need to change this orientation so that the goal of the government towards agriculture can be achieved and to secure good future for agriculture.

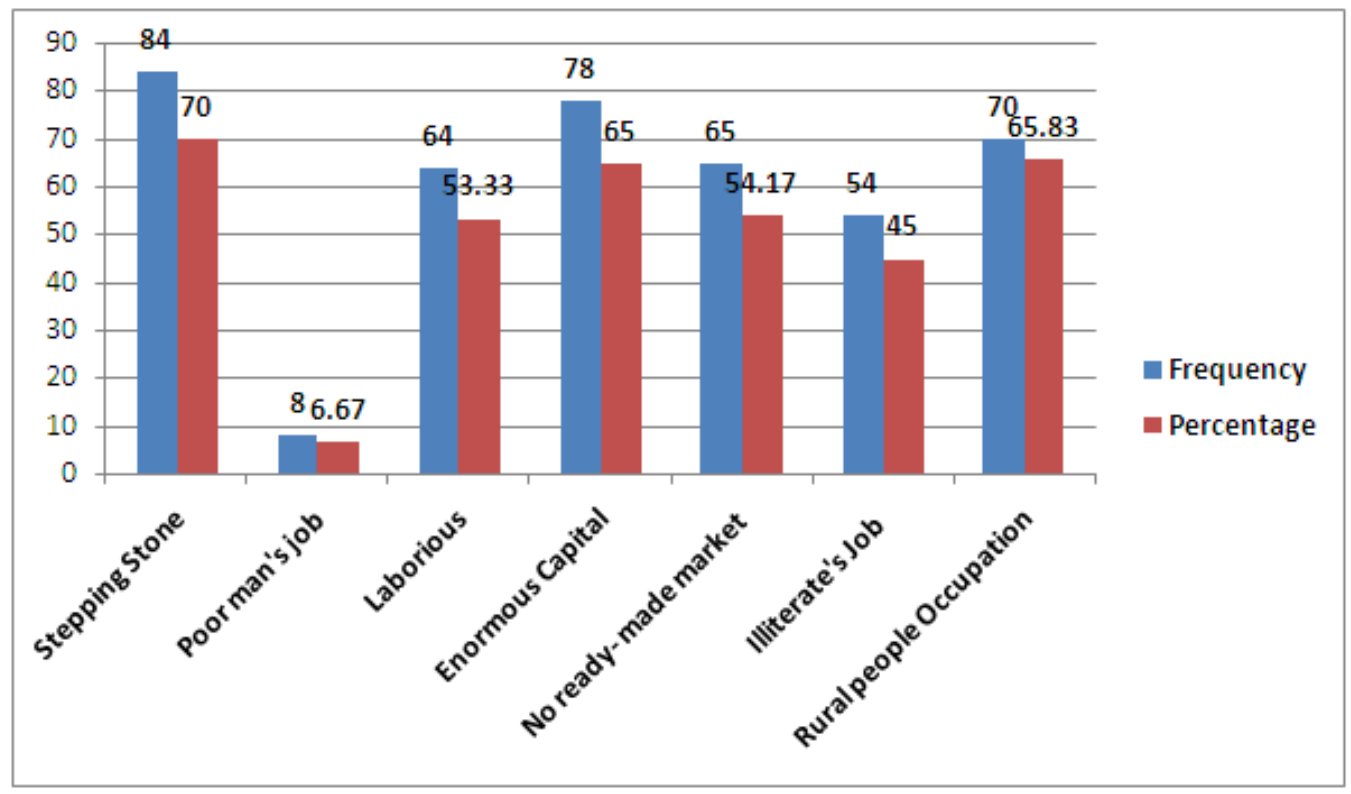

Fig.2 Perception of Respondent on Agricultural Profession

\subsection{Factors that influenced the choice of agricultural as a profession}

Table 2 reveals what/who influences the choice of agriculture career. $66.67 \%$ of the respondents were influenced by their previous educational performance, $56.67 \%$ were influenced by work experience, $35.83 \%$ were influenced by chance, $86.67 \%$ were influence by personal interest, $70 \%$ were influenced by media/contacts with agricultural expert, $76.67 \%$ were influence by their guidance and mentor, $73.33 \%$ were influence by their parents, $49.17 \%$ were influenced by their friends, $44.17 \%$ were influenced by their relatives, $53.33 \%$ were influenced by their brothers and sisters, $34.17 \%$ were influenced by the school attended, $58.33 \%$ were also influenced by the location of their childhood while gender discrimination has little $(19.17 \%)$ influence on the respondents. However, personal interest, parents and mentor greatly influence the students in the choice of 
deciding profession to pursue in life. Attempt was made to examine the level of influence of each factor on choice of career.

The variables were subjected to a 3 Likert scale point of strongly influence ( 3 points), slightly influence ( 2 points) and no influence ( 1 point) while variables greater than mean 1.84 were considered to influence choice of career and those ones less than mean 1.84 has no influence on career choice. Table 3 reveals seven variables that significantly influenced choice of career and their level of influence. Personal interest (mean $=2.50$ ) due to knowledge acquired in agriculture, Mentor and guidance (mean $=2.15)$, Parents $($ mean $=2.13)$, media and contact with agricultural experts (mean $=2.03)$, previous educational performance (mean $=2.01)$, location of childhood (mean $=1.96)$ and work experienced (mean $=1.92)$ respectively. This findings correspond with the findings of Adebo and Sekumade (2013), Azubuike (2011), Outley (2008), Esters and Bowen (2004), as well as Jones and Larke (2001), parents, environmental background, friends and educational performance significantly influence the choice of career among the youths in any profession.

Table 2. Who/what influenced choice of agricultural career

\begin{tabular}{lll}
\hline \multicolumn{1}{c}{ Table 2. Who/what influenced choice of agricultural career } \\
\hline Factors & Frequency & Percentage \\
\hline Previous Educational Performance & 80 & 66.67 \\
Work Experience & 68 & 56.67 \\
By Chance & 43 & 35.83 \\
Personal Interest & 104 & 86.67 \\
Media/ Contact with Ext. Personnel & 84 & 70.00 \\
Guidance/ mentor & 92 & 76.67 \\
Parents & 88 & 73.33 \\
Friends & 59 & 49.17 \\
Relatives & 53 & 44.17 \\
Brother/ Sister & 64 & 53.33 \\
School Attended & 41 & 34.17 \\
Gender Discrimination & 23 & 19.17 \\
Location of Childhood & 70 & 58.33 \\
\hline Filed Survey, 2014 & &
\end{tabular}

Source: Filed Survey, 2014.

Table 3. Level of Influence each factor on career choice

\begin{tabular}{|c|c|c|c|c|c|c|c|}
\hline Variable & $\begin{array}{c}\text { Strong } \\
\text { Influence }\end{array}$ & $\begin{array}{c}\text { Slightly } \\
\text { Influence }\end{array}$ & No Influence & $\begin{array}{c}\text { Total } \\
(\%)\end{array}$ & Mean & Decision & $\begin{array}{c}\text { Ranking of } \\
\text { Influence }\end{array}$ \\
\hline Previous & 123 & 78 & 40 & 241 & 2.01 & $\mathrm{~S}$ & $\mathrm{~V}$ \\
\hline Educational & (51.04) & $(32.37)$ & (16.59) & $(100)$ & & & \\
\hline Work & 126 & 52 & 52 & 230 & 1.92 & $\mathrm{~S}$ & VII \\
\hline Experience & $(54.78)$ & $(22.61)$ & $(22.61)$ & $(100)$ & & & \\
\hline Location of & 135 & 50 & 50 & 235 & 1.96 & $\mathrm{~S}$ & VI \\
\hline By chance & $(29.83)$ & $(27.62)$ & $(42.54)$ & $(100)$ & & & \\
\hline Personal & 228 & 56 & 16 & 300 & 2.50 & S & I \\
\hline Interest & (76) & (18.67) & $(5.33)$ & $(100)$ & & & \\
\hline Media & 120 & 88 & 36 & 244 & 2.03 & $\mathrm{~S}$ & IV \\
\hline Contact with & $(49.18)$ & $(36.07)$ & (14.75) & $(100)$ & & & \\
\hline \multicolumn{8}{|l|}{ Agril. Expert } \\
\hline Parents & $(56.25)$ & $(31.25)$ & $(12.5)$ & $(100)$ & & & \\
\hline \multirow[t]{2}{*}{ Friends } & 57 & 80 & 61 & 198 & 1.65 & NS & \\
\hline & (28.79) & $(40.40)$ & $(30.81)$ & $(100)$ & & & \\
\hline \multirow[t]{2}{*}{ Relatives } & 51 & 72 & 67 & 190 & 1.58 & NS & \\
\hline & (26.84) & $(37.89)$ & $(35.27)$ & $(100)$ & & & \\
\hline \multirow[t]{2}{*}{ Brother/ Sister } & 75 & 78 & 56 & 209 & 1.74 & NS & \\
\hline & (35.89) & $(37.32)$ & (26.79) & $(100)$ & & & \\
\hline School & 66 & 38 & 79 & 183 & 1.53 & NS & \\
\hline Attended & (36.07) & (20.77) & $(43.16)$ & $(100)$ & & & \\
\hline Gender & 12 & 38 & 97 & 147 & 1.23 & NS & \\
\hline Discrimination & $(8.16)$ & $(25.85)$ & $(65.99)$ & $(100)$ & & & \\
\hline
\end{tabular}

Source: Field survey, 2014.

\subsection{Barriers to continuing with agricultural profession}

Figure 2 reveals the barriers faced in taking up agricultural profession by respondents. $68.33 \%$ of the respondents indicated financial constraints, $76.67 \%$ indicated land acquisition problem and seasonality of agricultural commodities, $81.67 \%$ indicated that there is no stable and ready-made market for agricultural commodities, $78.33 \%$ indicated the problem of Perishability of agricultural produce, $70.00 \%$ indicated the 
problem of labour force, $45 \%$ indicated unpredictable future of agriculture, $60 \%$ indicated inadequate required skill, $62.5 \%$ indicated climate change and only $28.33 \%$ of the respondents indicated attitudinal problem of being called a farmer.

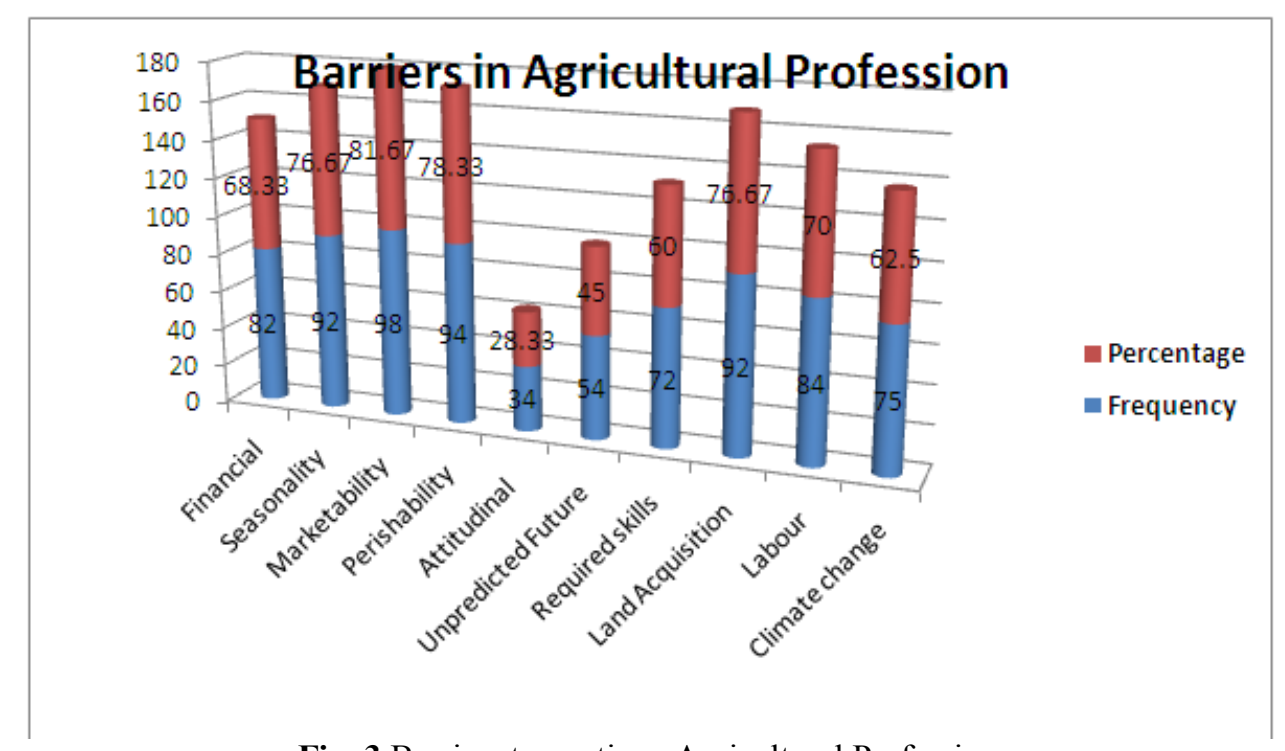

Fig. 3 Barriers to continue Agricultural Profession

\subsection{Estimates of Regression Model}

Table 4 reveals the estimation of simple regression model of the relationship between the choice of influence and the socio economic characteristics of the respondents. Age, work experience before admission, media and or contact with agricultural expert, Parents influence and family income have a significant influence on career choice of respondents. Parent influence, family income and work experience before admission all have a negative relationship on the choice of students on agricultural profession meaning that most of the students were in college of agriculture due to the financial capacity of the family, the job of the parents which have a direct link with their family income and also their experience on the farm before their admission into college of agriculture. Previous educational performance meaning that they find themselves in the college of agriculture because of their inability to meet up with the grade point of other institute and also guidance or mentor has a significant influence on their choice of career. This findings concur with the findings in table 2 meaning that before one can become a professional in agriculture, the previous educational experience is very important as agriculture is an applied science, hence basic knowledge of science courses are also fundamental.

Table 4. Estimates of Regression Model

\begin{tabular}{|l|c|c|}
\hline Variable & Coefficients & Standard Error \\
\hline Age & $1.3794 \mathrm{E}-07^{*}$ & $1.46675 \mathrm{E}-07$ \\
\hline Educational Performance & $0.080983647^{* *}$ & 0.041179503 \\
\hline Work Experience & $-0.054209104^{*}$ & 0.071778554 \\
\hline Gender & 0.232016747 & 0.04747258 \\
\hline Media/Contacts with Agril. Expert & $0.104882227^{*}$ & 0.054737932 \\
\hline Parent Influence & $-0.010092474^{*}$ & 0.031457437 \\
\hline Family Income & $-0.018482744^{*}$ & 0.009698514 \\
\hline Location of childhood & 0.145428915 & 0.06726123 \\
\hline Guidance/Mentor & $0.224129467^{* *}$ & 0.044429785 \\
\hline Personal interest & 0.013136912 & 0.04369319 \\
\hline
\end{tabular}

**Significant $5 \%$; *Significant at $1 \%$.

\section{Conclusion}

The study was carried out to identify the factors determining the choice of agricultural profession as a career among the students of College of Agriculture, Dr. Balasaheb Sawant Konkan Krishi Vidyapeeth, Dapoli, Maharashtra State, India. A total of 120 respondents were randomly selected from the students while structured questionnaire was used to elicit information from the students. Descriptive statistics, Likert scale, and simple regression model were used to analyze data collected. The respondents were young with average age of 22.6 years and they cut across all religious practices within the country but mostly Hindu. More than half (66.33\%) of the respondents were male, had childhood background in rural areas and from farming families. $70 \%$ of the 
respondents perceived agriculture as a stepping stone to other profession while others see it as poor and rural people's job, laborious, and it requires enormous capital.

Seven variables significantly influenced the choice of agricultural profession as a career. Personal interest $($ mean $=2.50)$, guidance or mentor $($ mean 2.15$)$, parents $($ mean $=2.13)$, media/contact with agricultural experts $($ mean $=2.03)$, previous educational performance $($ mean $=2.01)$, location of childhood $($ mean $=1.96)$ and work experienced (mean $=1.92$ respectively) and this is also validated by regression analysis. Some of the barriers for taking up agriculture as a life time profession includes; financial constraint, seasonality of agricultural commodities, marketability, perishability of agricultural produce, unpredicted future of agriculture, climate change, land acquisition, and labour.

\section{Recommendation}

The relevance of agriculture to the Indian economy cannot be over emphasized. In order to secure a future for the nation, there is an urgent need to stimulate the interest of the youths in agriculture early in life through career guidance and to inculcate the importance of the profession, as well as the spirit of farming in youths. Students should be encouraged to form Young Farmers Club and be active in carrying out operations on various farming enterprises. Ethics and benefits of the club should be made known to the students so as to tap the opportunities offered. The experiences gained in schools should be tailored towards commercial agriculture, ready-made market for farm produce, public storage facilities, rural electrification, land and credit facilities should be made available to graduate who want to embark on commercial agriculture shortly after graduation.

\section{References}

[1] India, (2011): Annual report 2010-11. New Delhi: Ministry of Agriculture, Department of Agriculture and Cooperation. http://agricoop.nic.in/AnnualReport10- $\quad$ 11/AGRICULTURAL\%20EXTENSION.pdf. Accessed March $21,2014$.

[2] Organisation for Economic Co-operation and Development (OCED) (2006): Annual Report, A Comprehensive Report of OCED activities $2005-2006$.

[3] K. Sundaram, (2001): "Employment and Poverty in 1990s, Further Results from NSS 55th Round, Employment-unemployment survey, 1999-00", Economic and Political Weekly, 11 August, pp.3039-49

[4] K. Sundaram, (2007): "Employment and Poverty in India, 2000-2005", Economic and Political Weekly, July 28, pp.3121-3131.

[5] N. Bloom and J. V. Reenen (2010): “Why do Management Practices Differ across Firms and Countries?" Journal of Economic Perspectives 24 (1) $203-224$.

[6] World Fact Book (2012): ?abour Force by Occupation, https://www.cia.gov/library/publications/the-worldfactbook/fields/print 2048.html.

[7] M. N. Ferry, (2006): Factors influencing career choices of adolescents and young adults in rural Pennsylvania. J. Exten. 44:3. http://www.joe.org/joe/2006june/index.php..

[8] O. C. Wilson (2008): Perceptions of agriculture and natural resource careers among minority students in a national organization www.treesearch.fs.fed.us/pubs/4063.

[9] D. McVicar (1996): School Quality and Staying-On: Resources, Peer Groups or Ethos? Northern Island Economic Research Centre. Working P. 45. www.qub.ac.uk/nierc.

[10] L. T. Esters and B. E. Bowen (2004): Factors influencing enrolment in an urban agricultural education program. J. Career. Technol. Edu.21:1.

[11] C. O. Azubuike (2011): Influential factors affecting the attitude of students towards vocational/technical subjects in secondary schools in Southeastern Nig. J. Edu. Soc. Res. 1(2).

[12] C. Hammond, D. Linton, J. Smink and S. Drew (2007): Dropout risk factors and exemplary programs, a technical report, National Dropout Prevention Center at Clemson. Retrieved November 9, 2007, from: http://www.cisnet.org/member/library/ resources/downloads/Dropout Risk Factors and Exemplary Programs FINAL 5-16-07.pdf.

[13] E. P. Faulkner (2009): Attitudes, educational, and career choices of foodand agricultural sciences institute participants. J. Agric. Edu. 50(1):45-56. DOI: 10.5032/jae.2009.01045.

[14] Census of India, (2011): House-listing and Housing Census Schedule". Government of India. Retrieved 22 January 2011.

[15] Adebo, A.G. and Sekumade, A. B. (2013): Determinant of Career choice of Agricultural Profession among the students of the Faculty of agricultural Sciences in Ekiti State University, Nigeria. JAERD Vol. 5 (11), Pp. 249 - 255.

[16] Jones WA, Larke A (2001). Factors influencing career choice of African-American and Hispanic graduates of a land-grant college of agriculture. J. Agric. Edu. 42(1):38.48. 